\title{
Financial and Strategic Pricing Analysis in the Development Market Using an Econometric Model
}

\author{
Ainur A. Akhmetzianov ${ }^{1} \&$ Andrew Y. Sokolov ${ }^{1}$ \\ ${ }^{1}$ Department of Accounting, Institute of Management, Economics and Finance, Kazan Federal University, Kazan, \\ Russia \\ Correspondence: Andrew Y. Sokolov, Department of Accounting, Institute of Management, Economics and Finance, \\ Kazan Federal University, Kazan, Russia. E-mail: sokolov-kzn@bk.ru
}

Received: September 1, 2020

Accepted: October 20, 2020

Online Published: December 24, 2020

doi:10.5430/ijfr.v12n1p144

URL: https://doi.org/10.5430/ijfr.v12n1p144

\begin{abstract}
This article demonstrates the use of a financial and econometric model with dummy variables to calculate the average price in the real estate market. The average price is used in the model for calculating project effectiveness and allows you to evaluate the profitability of the project at the construction planning stage. The number of rooms, the presence of a balcony, the number of sides of the windows and the number of floors were used as independent variables. A model with these factors showed qualitative estimates and can be applied for the purpose of forecasting prices in standard projects in the Russian real estate market.
\end{abstract}

Keywords: strategic management accounting, dummy variables, ANCOVA-model, pricing, forecasting, performance, profitability, real estate market

\section{Introduction}

Regarding the dynamic evolvement of the development market, the business feels an increasing need for reliable information concerning the housing market. The primary reason is that the strategic management of the enterprise relies on the assessment of market value, which is vital to increase efficiency.

Market value is the most probable price that a buyer is prepared to pay for a residential property without any coercion. This is due to the stochastic nature of the market itself as an economic system and the functioning, which occurs under the influence of many factors. All this predetermines the assessment process's probabilistic nature. Also, it makes it worthwhile to use procedures based on probabilistic analysis principles. These principles permit one to reasonably pick the model that best fits the initial statistical data characterizing the studied set of objects' actual behavior to evaluate the conclusions' reliability and accuracy. Real estate pricing models promoted for use in different structures vary in assessment approaches and model parameters. The basis for constructing econometric models for real estate valuation is determining the dependence of an object's cost characteristic on the totality of factors affecting price formation.

\section{Literature Review}

Many scientists and many works analyze real estate pricing issues have been devoted to them. Many factors affect pricing. By analyzing these factors, you can bring about a pricing model for a development organization. Having Utilized econometric tools, one can qualitatively select factors that will provide a reliable estimate of the price of real estate.

For example, N. Apergis and E. Geka use the A Vector Autoregression (VAR) and Vector Error Correction (ECVAR) models to study the effects of macroeconomic variables such as inflation on real estate prices in Canada, the U.K., and Japan. They argue that Variance Decompositions reflect that inflation is a variable with quite a large explanatory potential for real estate price variation. (Apergis \& Geka, 2012)

E. Ghysels and others review the evidence of predictability in U.S. residential and commercial real estate markets. They highlight the main methodologies used in the construction of real estate indices, their underlying assumptions and their impact on the stochastic properties of the resultant series. (Ghysels, 2013)

I. Semenko and J. Yoo studied direct real estate returns are correlated with shifts in weather patterns, which are proxied by changes in four moments of distribution for differences in average and maximum daily temperatures, deviations from optimal temperatures and climate risk index. This proves that there are many factors that directly affect the price 
of real estate, which can also be used for forecasting. (Semenenko \& Yoo, 2019)

Y. Wang, J. Liu and others assume that House price is affected by households' expectations of future house price trend and volatility, where the expected volatility of housing capital return, indicated by variance, is defined as the housing market risk. (Wang et al., 2020)

N. K. Kishor and H. A. Marfatia study the dynamic relationship among house prices, income and interest rates in 15 OECD countries. They find that any disequilibrium in the long-run cointegrating relationship among these variables is corrected by the subsequent movement in house prices in most of these countries. (Keppel, 1991)

Summarizing, we can say that there are many factors that could influence the price of real estate, but in order to evaluate and use them correctly, it is necessary to use econometric tools.

\section{Methodology}

We construct an econometric model to determine the average market price, which will be used as a basis in the pricing model. The resulting prices of 169 apartments are divided by the number of apartments, and we get the average market price, which we will use in the pricing model. Average costs are calculated based on the total cost of the project, plus various incremental coefficients depending on various parameters of the apartments. It is necessary to emphasize the importance of the average market price calculated in such a way, its meaning is that this price is fair and enables us, including determining whether the project can be profitable at existing prices and costs on the market. If, using this average market price, we get a low percentage of project profitability, and then we should revise the project indicators.

In the general case, a model with dummy variables has the form (formula 1) (Draper \& Smith, 1998) (Kennedy, 2003 \& Wooldridge, 2009):

$$
y=f\left(x_{1}, \ldots x_{p}, d_{11}, d_{12}, \ldots, d_{21}, d_{22}, \ldots, d_{j 1}, d_{j 2}, \ldots \varepsilon\right)
$$

Where $\mathrm{y}$ - dependent variable;

$\boldsymbol{x}_{1}, \boldsymbol{x}_{2}, \ldots, \boldsymbol{x}_{\boldsymbol{p}}$ - quantitative independent variables,

$\boldsymbol{d}_{\mathbf{2 1}}, \boldsymbol{d}_{\mathbf{2 2}}$ - dummy variables corresponding to the categories of the first non-quantitative indicator;

$\boldsymbol{d}_{\mathbf{2 1}}, \boldsymbol{d}_{\mathbf{2 2}} ;$ - - dummy variables corresponding to the categories of the second non-quantitative indicator;

$\boldsymbol{d}_{\boldsymbol{j} 1}, \boldsymbol{d}_{\boldsymbol{j} 2}$ - dummy variables corresponding to categories of the $\mathrm{j}$-th non-quantitative indicator;

$\varepsilon$ - random residue.

Regression models, in which the explanatory variables are both quantitative and qualitative, are called ANCOVA models (models of covariance analysis) (Keppel, $1991 \&$ Leppink, 2018). ANCOVA-model in the presence of a dummy variable shift of two alternatives.

We have obtained data on apartment surveys for three similar development projects with 169 apartments. The price was chosen as the dependent variable, and $\mathrm{R}$ - was the number of rooms as the quality independent variables; B balcony; $\mathrm{WSi}$ - is the number of sides of the exit windows and the quantitative independent variable $\mathrm{F}$ - is the floor.

We analyzed several models, as a result, we chose the Least square method model adjusted for heteroskedasticity, since all other models showed the presence of heteroskedasticity.

\section{Results}

We obtained the following model results in the Gretl environment (Table 1).

Table 1. The regression model with dummy variables [compiled by the author]

\begin{tabular}{llllll}
\hline & Coefficient & Std. Error & t-ratio & $p$-value & \\
\hline const & 40429.6 & 734.871 & 55.0159 & $<0.0001$ & $* * *$ \\
\hline R1 & 19003.7 & 410.367 & 46.3091 & $<0.0001$ & $* * *$ \\
\hline R2 & 4600.81 & 597.171 & 7.7043 & $<0.0001$ & $* * *$ \\
\hline B54 & 3154.24 & 536.439 & 5.8800 & $<0.0001$ & $* * *$ \\
\hline WSi1 & -5688.1 & 623.915 & -9.1168 & $<0.0001$ & $* * *$ \\
\hline F & 1781.38 & 39.7913 & 44.7682 & $<0.0001$ & $* * *$ \\
\hline
\end{tabular}

Model PM: Heteroskedasticity-corrected, using observations 1-507

Dependent variable: Price 
Statistics based on the weighted data:

\begin{tabular}{lcll}
\hline Sum squared resid & 1471.455 & S.E. of regression & 1.713778 \\
\hline R-squared & 0.898825 & Adjusted R-squared & 0.897815 \\
\hline F(5, 501) & 890.1623 & P-value(F) & $1.5 \mathrm{e}-246$ \\
\hline Log-likelihood & -989.5051 & Akaike criterion & 1991.010 \\
\hline Schwarz criterion & 2016.381 & Hannan-Quinn & 2000.960 \\
\hline
\end{tabular}

Statistics based on the original data:

\begin{tabular}{llll}
\hline Mean dependent var & 66753.53 & S.D. dependent var & 12157.43 \\
\hline Sum squared resid & $1.02 \mathrm{e}+10$ & S.E. of regression & 4513.504 \\
\hline
\end{tabular}

In this table, you can see that the main indicators of the observed model are presented. We considered 5 indicators, for each of them the values of the coefficients, standard error, t-statistics, P-values are given. You can also analyze the sum of the squared residuals, the standard error of the model, the R-squared and the corrected R-squared, the value of the Fisher test, Akaike criterion, Hennan-Quin and Schwartz.

We obtain the following equation (2):

$$
\text { Price }=40429.6+18877.2 * \mathrm{R} 1+4320.34 * \mathrm{R} 2+3136.46 * \mathrm{~B} 54-5861.44 * \mathrm{WSi} 1+1781.50 * \mathrm{~F}
$$

The observed values of Student t-statistics and the results of testing the hypothesis of the insignificance of the coefficients confirm that the coefficients are significant at the level of $99 \%$. The corrected R-square is $89.78 \%$, which means a high relationship of indicators. The observed value of Fisher's F-statistics and the results of testing the hypothesis of the insignificance of the model as a whole show that the model is adequate to sample data. The tests for heteroskedasticity and the schedule of residues revealed its presence in the residues $(\mathrm{p}<0.05)$; therefore, as we mentioned earlier, we used a special model corrected for heteroskedasticity.

Checking the residuals for the normality of the model gave the following results, which are shown in figure 1. In this graph, you can see that the residuals are generally normally distributed, and the test for normal distribution confirms this.

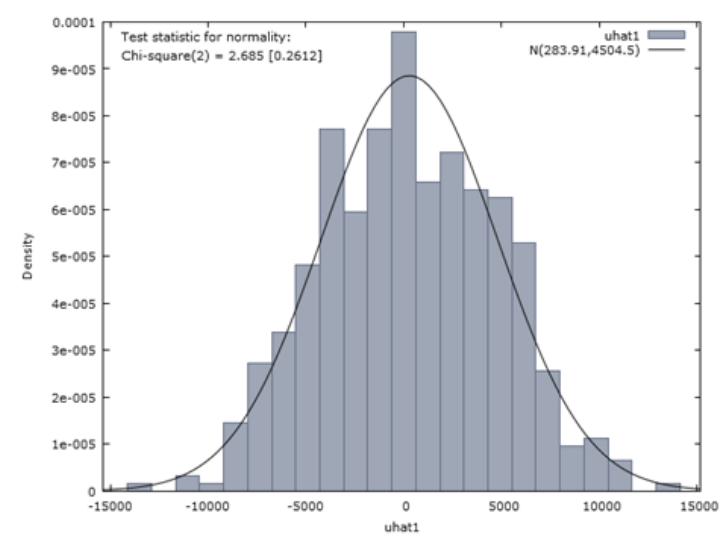

Figure 1. Test for the normal distribution of residues in the model without dummy variables [compiled by the author] Based on the results, it can be concluded that the normal distribution law is observed ( $p>0.05)$.

Based on the available observations, we estimated the predictive qualities of the model.

Average percentage error: MPE $=-0.072505$.

Mean absolute percentage error: $\mathrm{MAPE}=5.6878$. 
These results are quite low, which means good predictive qualities of the model.

The coefficients of the regression model obtained by us allow us to construct equations for each type of apartment and to obtain the predicted selling price per square meter (Table 2).

Table 2. Sales price equations for a typical apartment

\begin{tabular}{|c|c|c|}
\hline № & Type of apartment & Equation \\
\hline 1 & $\begin{array}{l}\text { One-room apartment with a large balcony, } \\
\text { one-way windows, on floor } F\end{array}$ & $\begin{array}{l}\text { Price }=40429.6+19003.7 * 1+4600.81 * 0+ \\
3154.24 * 1-5688.1 * 1+1781.38 * \mathrm{~F}\end{array}$ \\
\hline 2 & $\begin{array}{l}\text { Two-room apartment with a large balcony, } \\
\text { windows face one side, on floor } \mathrm{F}\end{array}$ & $\begin{array}{l}\text { Price }=40429.6+19003.7 * 0+4600.81 * 1+ \\
3154.24 * 1-5688.1 * 1+1781.38 * \mathrm{~F}\end{array}$ \\
\hline 3 & $\begin{array}{l}\text { Three-room apartment with a large balcony, } \\
\text { windows face one side, on floor } F\end{array}$ & $\begin{array}{l}\text { Price }=40429.6+19003.7 * 0+4600.81 * 0+ \\
3154.24 * 1-5688.1 * 1+1781.38 * \mathrm{~F}\end{array}$ \\
\hline 4 & $\begin{array}{l}\text { One-room apartment with a small balcony, } \\
\text { windows face one side, on floor } \mathrm{F}\end{array}$ & $\begin{array}{l}\text { Price }=40429.6+19003.7 * 1+4600.81 * 0+ \\
3154.24 * 0-5688.1 * 1+1781.38 * \mathrm{~F}\end{array}$ \\
\hline 5 & $\begin{array}{l}\text { Two-room apartment with a small balcony, } \\
\text { windows face one side, on floor } \mathrm{F}\end{array}$ & $\begin{array}{l}\text { Price }=40429.6+19003.7 * 0+4600.81 * 1+ \\
3154.24 * 0-5688.1 * 1+1781.38 * \mathrm{~F}\end{array}$ \\
\hline 6 & $\begin{array}{l}\text { Three-room apartment with a small balcony, } \\
\text { windows face one side, on floor } \mathrm{F}\end{array}$ & $\begin{array}{l}\text { Price }=40429.6+19003.7 * 0+4600.81 * 0+ \\
3154.24 * 0-5688.1 * 1+1781.38 * \mathrm{~F}\end{array}$ \\
\hline 7 & $\begin{array}{l}\text { One-room apartment with a large balcony, } \\
\text { two-sided windows, on floor } \mathrm{F}\end{array}$ & $\begin{array}{l}\text { Price }=40429.6+19003.7 * 1+4600.81 * 0+ \\
3154.24 * 0-5688.1 * 0+1781.38 * \mathrm{~F}\end{array}$ \\
\hline 8 & $\begin{array}{l}\text { Two-room apartment with a large balcony, } \\
\text { windows face two sides, on floor } \mathrm{F}\end{array}$ & $\begin{array}{l}\text { Price }=40429.6+19003.7 * 0+4600.81 * 1+ \\
3154.24 * 0-5688.1 * 0+1781.38 * \mathrm{~F}\end{array}$ \\
\hline 9 & $\begin{array}{l}\text { Three-room apartment with a large balcony, } \\
\text { windows face two sides, on floor } \mathrm{F}\end{array}$ & $\begin{array}{l}\text { Price }=40429.6+19003.7 * 0+4600.81 * 0+ \\
3154.24 * 0-5688.1 * 0+1781.38 * \mathrm{~F}\end{array}$ \\
\hline
\end{tabular}

Source: compiled by the author.

Thus, substituting the coefficient values into this model, we can get the average selling price per square meter in a typical project and use it as an expert estimate in the pricing model.

Using the regression equation, we were able to calculate the average value of the dependent variable price, it amounted to 66,754 rubles.

Our goal in the pricing model is to calculate the price list for a typical apartment, as well as to evaluate the profitability of each development object. Therefore, as the variables used in the model, we used: the number of rooms, sales area, type of balconies, number of floors and the number of sides onto which the windows open. We suggested that depending on these factors, there may be a different selling price, and accordingly, we calculated the corresponding coefficients of the influence of each factor on the price. Having received the sale price for each type of apartment, we compared them with the costs and received an indicator of project profitability in the decoding of apartments.

\section{Summary}

Thus, the use of an econometric model is an effective way that allows you to find the average market price and use it in your calculations. Our pricing model allows us to get a price and calculate the effectiveness of the project. Also, based on this model, we received confirmation that at the level of costs that the company is building, it can be cost-effective in the context of prevailing average market prices.

\section{Discussion and Conclusions}

A pricing model has been proposed that takes into account the influence of various factors using an econometric model with dummy variables to determine a fair market price. Using this model, we calculated the average price that we used in calculating the effectiveness of a development project. This model has shown quite good results and can be used by development companies. Of course, the factors used may be modified or supplemented by others. But, in our opinion, in the Russian market, these factors objectively reflect reality. 


\section{Acknowledgments}

The work is performed according to the Russian Government Program of Competitive Growth of Kazan Federal University.

\section{References}

Apergis, N., \& Geka, E. (2012). Real estate prices and inflation. International Journal of Economic Research, 9(2).

Draper, N. R., \& Smith, H. (1998). Applied regression analysis (Vol. 326). John Wiley \& Sons.

Ghysels, E., Plazzi, A., Valkanov, R., \& Torous, W. (2013). Forecasting real estate prices. In Handbook of economic forecasting (Vol. 2, pp. 509-580). Elsevier.

Keppel, G. (1991). Design and analysis: a researcher's handbook (3rd ed., p. 594). Prentice Hall, Englewood Clifts, New York.

Kishor, K. N., \& Marfatia, H. A. (2017). The dynamic relationship between housing prices and the macroeconomy: Evidence from OECD countries. Journal of Real Estate Finance and Economics, 54(2), 237-268. https://doi.org/10.1007/s11146-015-9546-8

Leppink, J. (2018). Analysis of covariance (Ancova) vs. moderated regression (Modreg): why the interaction matters. Health Professions Education, 4. https://doi.org/10.1016/j.hpe.2018.04.001

Peter, K. (2003). A guide to econometrics (5th ed., pp. 249-250). Cambridge: The MIT Press.

Semenenko, I., \& Yoo, J. (2019). Climate Change and Real Estate Prices. International Journal of Economics and Finance, 11(11).

Wang, Y., Liu, J., Tang, Y., \& Sriboonchitta, S. (2020). Housing Risk and Its Influence on House Price: An Expected Utility Approach. Mathematical Problems in Engineering.

Wooldridge, J. M. (2009). Introductory econometrics: a modern approach (p. 865). Cengage Learning.

\section{Copyrights}

Copyright for this article is retained by the author(s), with first publication rights granted to the journal.

This is an open-access article distributed under the terms and conditions of the Creative Commons Attribution license (http://creativecommons.org/licenses/by/4.0/). 